\title{
The Use of Satellite Imagery for Land Use Updating
}

\author{
MS Khabibur Rahman \\ Universitas Veteran Bangun Nusantara \\ Sukoharjo, Indonesia \\ khabib_ynwa@yahoo.co.id
}

\author{
Abdul Hamid \\ Universitas Veteran Bangun Nusantara \\ Sukoharjo, Indonesia \\ realitakosong@gmail.com
}

\begin{abstract}
The aims of this research is to determine the land use changes in Sawit Sub-Sub-District of Boyolali on 2005-2015 by using satellite imagery and GIS aplications. The research method is used descriptive method, which is provide an overview of land use changes that occured from 2005-2015 in Sawit Sub-Sub-District using map. Data collected from satellite imagery as the basic data of this research which is processed using GIS aplications with data validation by using data triangulation. This data is compared every 5 years, and then the land use changes are analyzed. The final result of this research is the land use changes for 10 years in Sawit Sub-SubDistrict of Boyolali. The land changes taht occured from 20052010 were of two types, they are rice fields into sattlements and rice fields into garden, while in 2010-2015 there were three types of the land use changes, namely rice fields into settlements, rice fields become garden and garden into settlements. The most land use change is a reducted in utilization of rice fields and increasing the settlements. By utilizing the satellite imagery and GIS applications, it will be easier to observe the land use changes, and then it can updating the land use according to the desired time and image availability.
\end{abstract}

\section{Keyword: GIS application, land use, satellite imagery.}

\section{INTRODUCTION}

Land is a state of land that has already been designated and has been owned by someone or an institution. Land is an important element in human life as a space and a resource, because most of human life depends on land that can be used as a source of livelihood, namely by earning a living through certain businesses other than as a settlement. physical surface of the earth. Factors that cause changes in land use are the increasing population, while the land area remains.

Natural population growth and migration is one of the causes of increasing space needs which will also have an influence on the increasing need for settlements and other supporting facilities. The existence of this population increase will affect the increasing development activities that cause changes in land use. Likewise, what happened in Sawit Sub-District, Boyolali Regency, with increasing population, the rate of land use change also increased. However, the problem is that there is no data related to the details of land use changes that have occurred.

\section{MATERIALS AND METHODS}

\section{A. Changes in Land Use}

The definition of land is different from land, where land is one aspect of land. Land resources can be interpreted as physical resources consisting of climate, topography, land, hydrology, and vegetation where certain limits affect land use capability. [6]

According to the environment minister's regulation number 17 of 2009 that land is an area whose characteristics encapsulate all biosfir, atmospheric, soil, geological, relief, hydrology, plant and animal populations, and the results of human activities past and present, which are steady or reconcile.[2] The meaning from the word sedentary can also mean that humans use the land they have as a place to live and get their necessities of life.

Based on these two meanings, it can be interpreted that the land is part of space is an important element in human life as space and resources, because most of human life depends on land that can be used as a source of livelihood, namely by earning a living through certain businesses other than as a settlement.

Land use change is an increase in land use from one side of use to another, followed by a reduction in the type of land use from one time to the next, or a change in the function of a land at different times. [8]

In learning land use change can be done with several approaches, one of which is a spatial approach. Land use is closely related to the local environment, both mutually influential, and interdependent relationships. The linkage of land use with the aspect of the area, shown in this application for land conservation and for the basis of regional development planning. The use of land that does not heed the preservation of resources will lead to environmental deterioration, which means it has a negative impact on human life itself. People who always experience changes in the number and activities of their lives, directly or indirectly, have an impact on the shape and extent of land use, which in turn results in a decrease in land potential in the production of food.

Prevention of the negative impacts of land use change is by periodic data collection on land use changes that occur. With the knowledge of the rate of change in land use, the control of land degradation will be easier. The easiest and cheapest way is to utilize technology in the form of satellite imagery combined with a GIS application, resulting in a map showing areas that have experienced land use change.

\section{B. Remote Sensing and Mapping}

Remote Sensing is the science and art of obtaining information about an object, area or phenomenon by analyzing data obtained with a device without direct contact with objects, regions or phenomena being studied $^{[1]}$. The basic concept of remote sensing consists of several components that include sources of energy, atmosphere, interaction of forces with objects on the earth's surface, sensors, data processing systems and 
various data users. Data acquisition can be done by means of digital or manual image interpretation. Remote sensing is a data source that can be used to analyze land use. One example of remote sensing imagery is google earth.

Google Earth is a virtual globe program that is actually called Earth Viewer and is made by Keyhole, Inc. This program maps the earth from several image positions collected from satellite mapping, aerial photography and 3D GIS globe. The image in Google Earth comes from a collection of satellite images and aerial photographs. Google earth is basically a collection of images and aerial photographs that have a low to high resolution. The image of the very high spatial resolution used by Google Earth can be used for excellent detail scale mapping. Examples of high spatial resolution images such as Ikonos, Quickbird, or Geo Eye imagery. This high resolution image is used for data in the form of land use.

The image generated by remote sensing will be processed using GIS then displayed in map form. The purpose of describing changes in land use by using a map is to make it easier for data users to find out the location that has changed. Map is a communication medium between map makers with map readers / users. What is intended by the mapmaker and contained in the maps made, is expected to be well interpreted by the map reader[5].

The connection between land use change and remote sensing is remote sensing is a periodic data provider regarding land use in high resolution, so that land use changes every year can be seen from remote sensing images at the same location in different time periods. To make it easier to observe these changes, a map of land use changes will be made within a certain period of time that describes the locations that experienced changes in land use. Taiwo said that "The use of remote sensing and landscape metrics provides opportunity to quantify the urban expansion process and estimate the impact of such expansion. The use of remotely sensed data provides an opportunity to compare urban growth over time, and growth across different political dispensations." ${ }^{[7]}$

\section{Method}

This research was conducted in Sawit Sub-District, Boyolali Regency. The research method used is descriptive by describing the map of land use change in the study area. ${ }^{[4]}$ The source of the data comes from digital satellite images compiled from google earth and then triangulated the data with field surveys. Data analysis techniques were carried out by analyzing the map resulting from overlaying the land use map between five years.

\section{RESULT AND DISCUSSION}

\section{A. Result}

The results of the research that have been carried out get an overview of the land use maps Sawit SubDistrict of Boyolali in 2005, 2010 and 2015. The map of land use in 2005 compared to 2010, then in 2010 compared to 2015. The results of image interpretation after being processed into the 2005 land use map shows the following results:

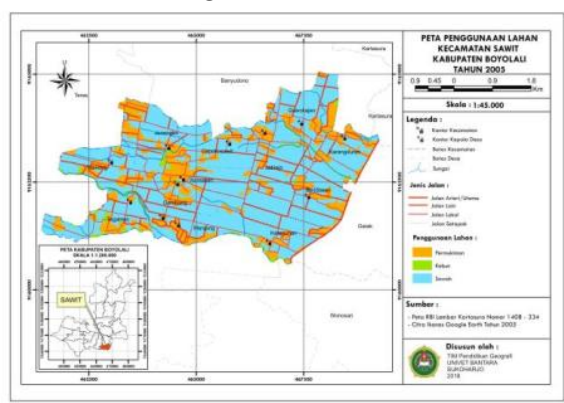

Picture 1. Land Use Map of Sawit Sub-Sub-District in Boyolali in 2005 (scale not taken into account)

From the land use map above, the results show that the majority of land use is rice fields of $75.6 \%$ and the smallest is the use of garden land which includes $2.5 \%$ of vacant / open land. Land use for settlements in 2005 at the research location was $21.9 \%$. The condition of land use which is mostly non-built (rice fields and garden) is very good to be maintained, because nonland use is built very well for water catchment areas.

After creating a land use map in 2005, a land use map was made in 2010 with the following results:



Picture 2. Land Use Map at Sawit Sub-District of Boyolali in 2010 (scale not taken into account)

Based on the calculation of the land use area above, the majority of the land designated for rice fields is $74.5 \%$, settlements are $22.5 \%$ and gardens are $3 \%$. Comparing with land use in 2005 , there was a change in land use in each designation. Within a period of 5 years, there was a decrease in the area of rice field designation by $1.1 \%$ and an additional residential area of $0.6 \%$ and a $0.5 \%$ garden. For more details, the locations that experience land use changes can be seen on the following map: 


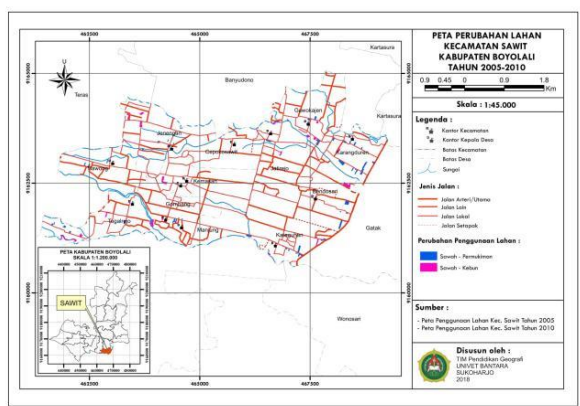

Picture 3. Map of Changes in Land Use in Sawit SubDistrict of Boyolali at 2005-2010 (scale not taken into account)

After the change of land use was discovered in 2005-2010, then land use was prepared in 2015 interpreted from the image of Google Earth. The results of the 2015 land use interpretation can be seen on the following map:

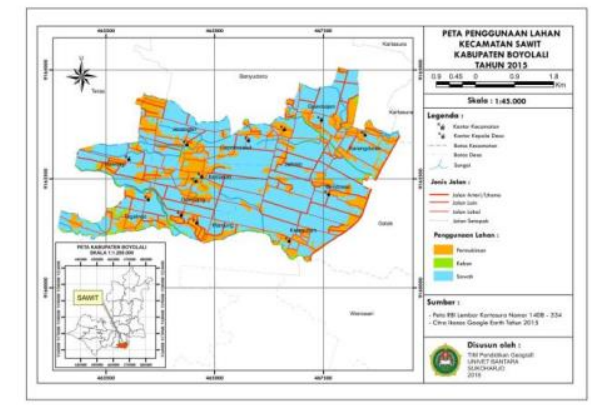

Picture 4. Land Use Map Sawit Sub-District of Boyolali in 2015 (scale not taken into account)

Based on the map above it is known that the area of land use land use is $72.6 \%$, the allocation of housing is $24.3 \%$ and the garden is $3.1 \%$. Compared to the land use in 2010, land use changes occurred, namely the reduction of land use fields from $74.5 \%$ to $72.6 \%$, or a decrease of $1.9 \%$. Resettlement allocation increased from $22.5 \%$ to $24.3 \%$ or increased $1.8 \%$ and gardens experienced a $1 \%$ increase from before. For more complete areas that experience land use changes in 2010-2015 can be seen on the following map:



\section{B. Discussion}

Utilization of satellite imagery on Google Earth is very helpful in analyzing periodic land use changes.
Changes in land use in the Sawit Sub-District of Boyolali Regency can be observed from the interpretation of images quoted from Google Earth. The most frequent changes were the decline in the designation of rice fields, which initially in 2005 was $75.6 \%$ to $74.5 \%$ in 2010 and $72.6 \%$ in 2015 . This shows that the rice field area in Sawit Sub-Sub-District experienced a $3 \%$ decline in the period ten years.

The land use allocation that has increased is settlement. In 2005 the allocation of settlements in Sawit Sub-District was 21.9\% of the total area, in 2010 it increased by $0.6 \%$ to $22.5 \%$ then in 2015 it became $24.3 \%$. The total addition of residential land use use is $2.4 \%$ of the total area of Sawit Sub-District. The allocation of garden land use also experienced an increase in 2005 the allocation of gardens by $2.5 \%$, increased to $3 \%$ in 2010 and to $3.1 \%$ in 2015 . Although it did not experience a significant increase, the use of garden land also reduced use paddy fields.

Population growth has a large influence on land use changes that occur. From BPS data from Boyolali Regency, it was found that the total population of Sawit Sub-District in 2005 was 32,791 people, increasing in 2010 to 32,993 people and in 2014 as many as 33,027 people. Population growth is of course followed by the need for settlements, as indicated by the increase in the allocation of residential land use by $2.4 \%$ within 10 years.

The advantage of using Google Earth's image in the analysis of land use change is data that is faster to obtain, cheaper and more manageable. The monitoring of land use changes can be used as a policy study material in making decisions regarding permits in land use. The disadvantage is that Google Earth is a free image provider, so the data displayed cannot be as desired, but can be overcome if the user purchases an image / aerial photo.

\section{CONCLUSION}

The results showed that the use of satellite imagery to update land use was very helpful. Analysis of changes in land use in Sawit Sub-District of Boyolali showed a change in land use land use which experienced a decline, while the land use allocation of settlements and gardens experienced an increase. The description of changes in land use using maps provides convenience for users to find out the distribution of locations that have changed.

The selection of google earth's image as the basic data provides benefits including easy to obtain, fast processing, and reliable data accuracy. The use of remote sensing (in this case is google earth) as a basic data for updating land use should be improved and optimized considering the various benefits obtained. Ease of processing data is also one of the advantages in the use / utilization of remote sensing.

\section{REFERENCE}

[1] Lillesand, Thomas M \& Kiefer,Ralph W. Penginderaan Jauh dan Interpretasi Citra. Terjemahan (pp : 145)Yogyakarta, Indonesia : Gadjahmada University Press. 1990 
[2] Peraturan Menteri Lingkungan Hidup Nomor 17 Tahun 2009 Tentang Pedoman Penentuan Daya Dukung Lingkungan Hidup Dalam Penataan Ruang Wilayah.

[3] Partono, Bambang and Rahman, MS Khabibur. "Development of Tourism Site on the Narrow Land (Case Study Dam Colo, Nguter Sub-District of Sukoharjo)." International Journal of Research in Tourism and Hospitality (IJRTH), vol 3, no. 4, 2017, pp. 25-29. doi:http://dx.doi.org/10.20431/2455-0043.0304003

[4] Partono, Bambang \& Rahman, MS Khabibur. Pemanfaatan Sistem Informasi Geografis (SIG) untuk Pemetaan Wisata Alam dan Budaya Sebagai Usaha Perkembangan Kabupaten Sukoharjo. Paper presented at The 15th Simposium Nasional RAPI, (pp. 436441).Surakarta, Indonesia. 2017.

[5] Rahman,MS Khabibur , \& Rohsulina, Pranichayudha. Pemetaan Sarana Prasarana SD Negri di Kecamatan Sukoharjo Berdasarkan permendiknas Nomor 24 Tahun 2007. Jurnal GEOEDUKASI, 4 (1), 49-54.

http://jurnalnasional.ump.ac.id/index.php/GeoEdukasi/article/view/53 ‥ 2015.

[6] Rayes, M. Luthfi. Metode Inventarisasi Sumber Daya Lahan. (pp:2) Yogyakarta. Indonesia : Andi. 2007.

[7] Taiwo, Jhon. Urban Growth During Civilian and Military Administrations in Osogbo, Nigeria. Indonesian Journal of Geography. Vol. 50 No. 1, June 2018 (1- 10) DOI: http://dx.doi.org/10.22146/ijg.13002. 2018.

[8] Wahyunto, dkk. Studi perubahan penggunaan lahan di Sub DAS Citarik, Jawa Barat dan DAS Kaligarang, Jawa Tengah. dalam Prosiding Seminar Nasional Multifungsi Lahan Sawah. Bogor, 1 Mei 2001. Departemen Pertanian, Badan Penelitian dan Pengembangan, Pertanian Pusat Penelitian dan Pengembangan Tanah dan Agroklimat. (pp 39 -63) Bogor, Indonesia. 2001. 